\title{
A monomeric, heterobimetallic complex with an unsupported Mg-Fe bond
}

Christopher Birchall, Graeme J. Moxey, Jonathan McMaster, Alexander J. Blake, William Lewis, and Deborah L. Kays*

School of Chemistry, University of Nottingham, University Park, Nottingham, NG7 2RD, UK

\begin{abstract}
The phosphinimine, trimethylsilyl-substituted BIPM ligand [BIPM = bis(iminophosphorano)methanide] has been used to stabilise $\mathrm{CH}\left(\mathrm{Ph}_{2} \mathrm{PNSiMe}_{3}\right)_{2} \mathrm{MgFe}\left(\eta^{5}\right.$ $\left.\mathrm{C}_{5} \mathrm{H}_{5}\right)(\mathrm{CO})_{2}(\mathbf{1})$, which is a structurally authenticated complex exhibiting a direct, unsupported bond between an alkaline earth metal and a transition metal. The FTIR-measured carbonyl stretching frequencies for this complex suggest that there is a polarisation of charge from the transition metal fragment to the magnesium centre. The presence of a polar metal-metal bond in $\mathbf{1}$ is confirmed by DFT calculations, which suggest that the $\mathrm{Mg}-\mathrm{Fe}$ bond is predominantly ionic in nature.
\end{abstract}

Keywords: magnesium $\cdot$ iron $\cdot$ metal-metal interactions $\bullet \mathrm{N}$ ligands $\cdot$ density functional calculations 


\section{Introduction}

The investigation of compounds featuring metal-metal bonds is an area of intense research interest, both from a fundamental structure and bonding viewpoint, and also in areas such as catalysis and bioinorganic chemistry. ${ }^{1}$ In terms of structure and bonding, the investigation of metal-metal bonds within heterobimetallic complexes is particularly attractive due to the differing electronegativities of the metal centres resulting in ionic contributions to the bonding. ${ }^{2}$ Despite the potential cooperative reactivity between two metal centres with very different electronic configurations, heteronuclear compounds with highly polar metal-metal bonds have historically proven challenging to study as the differing redox properties of these metals have often prevented their synthesis and isolation. ${ }^{3}$ It is the investigation of such heterobimetallic compounds which do not exhibit bridging ligands which is a particular area of interest as the degree of covalent contributions to the bonding in heteronuclear metal-metal bonds cannot be predicted. $^{4}$

For unsupported bonds between a transition metal and an element from elsewhere in the periodic table, much recent progress has been made in the p-block, ${ }^{5}$ lanthanides ${ }^{6}$ and actinides, ${ }^{4,7}$ which is facilitating the systematic study of the nature of the bonding between these elements. There is, however, a paucity of analogous complexes of the s-block elements, and it is only in the last few years that the number of compounds with direct, unsupported bonds between an alkaline earth (Ae) metal and a transition metal (TM) has started to gather pace in the literature, ${ }^{8-17}$ and complexes featuring a $\mathrm{Be}-\mathrm{TM}$ bond ${ }^{11,16}$ and a $\mathrm{Ca}-\mathrm{TM}$ bond ${ }^{12}$ are incredibly scarce. The expansion of the scope of complexes featuring an unsupported bond between an alkaline earth and transition metal will aid the understanding of the fundamental structure and bonding within this family of heterobimetallic compounds. Herein we report the synthesis and characterisation of a complex possessing an unsupported $\mathrm{Mg}-\mathrm{Fe}$ bond along with DFT calculations, providing insight into the nature of the bonding in this complex. 
We have chosen to utilise the phosphinimine, trimethylsilyl-substituted BIPM ligand $[\mathrm{BIPM}=$ bis(iminophosphorano)methanide $],{ }^{18}$ given the ready access it provides to $\mathrm{CH}\left(\mathrm{Ph}_{2} \mathrm{PNSiMe}_{3}\right)_{2} \mathrm{MgI}(\mathrm{THF})(\mathrm{THF}=$ tetrahydrofuran $) .{ }^{19}$ With its synthetic utility for the stabilisation of complexes with highly reactive metal centres, it is surprising that this ligand has been little exploited in the stabilisation of complexes containing unusual metal-metal bonds, with only a handful of cases of its use in this context being reported. ${ }^{20}$

\section{Experimental Section}

\section{General}

All manipulations were performed under an argon or dinitrogen atmosphere using standard Schlenk line or glove box techniques. Toluene was pre-dried over Na wire and freshly distilled over sodium under argon, degassed and stored over a potassium mirror prior to use. Benzene$d_{6}$ (Goss) was dried over potassium and degassed with three freeze-pump-thaw cycles prior to use. Starting materials $\mathrm{CH}\left(\mathrm{Ph}_{2} \mathrm{PSiMe}_{3}\right)_{2} \mathrm{MgI}(\mathrm{THF})^{16}$ and $\mathrm{Na}\left[\mathrm{Fe}\left(\eta^{5}-\mathrm{C}_{5} \mathrm{H}_{5}\right)(\mathrm{CO})_{2}\right]^{21}$ were prepared according to literature methods. NMR spectra were recorded on a Bruker AV 400 spectrometer, and chemical shifts are quoted in ppm relative to TMS $\left({ }^{1} \mathrm{H},{ }^{13} \mathrm{C}\left\{{ }^{1} \mathrm{H}\right\}\right.$ and $\left.{ }^{29} \mathrm{Si}\left\{{ }^{1} \mathrm{H}\right\}\right)$ and $85 \% \mathrm{H}_{3} \mathrm{PO}_{4}$ solution in $\mathrm{H}_{2} \mathrm{O}\left({ }^{31} \mathrm{P}\left\{{ }^{1} \mathrm{H}\right\}\right)$. IR absorption spectra were recorded on a Bruker Tensor 27 FTIR spectrometer over a frequency range of 500-4000 $\mathrm{cm}^{-1}$. Elemental analysis was performed by $\mathrm{Mr}$ Stephen Boyer at the Microanalysis Service, London Metropolitan University.

Synthesis and spectroscopic data for 1: A mixture of $\mathrm{CH}\left(\mathrm{Ph}_{2} \mathrm{PSiMe}_{3}\right)_{2} \mathrm{MgI}(\mathrm{THF})(0.21 \mathrm{~g}$, $0.27 \mathrm{mmol})$ and $\mathrm{Na}\left[\mathrm{Fe}\left(\eta^{5}-\mathrm{C}_{5} \mathrm{H}_{5}\right)(\mathrm{CO})_{2}\right](0.06 \mathrm{~g}, 0.28 \mathrm{mmol})$ in toluene $(20 \mathrm{~mL})$ was stirred for 24 hours at room temperature. The toluene solution was filtered, concentrated and cooled to - 
$35{ }^{\circ} \mathrm{C}$ for 16 hours, whereupon $\mathbf{1}$ was isolated as a brown microcrystalline solid. Further concentration and storage at $-35{ }^{\circ} \mathrm{C}$ afforded a second crop of $\mathbf{1}$ (total yield $0.15 \mathrm{~g}, 71 \%$ ). Single crystals of $\mathbf{1}$ suitable for X-ray diffraction were grown from a concentrated toluene solution at $7{ }^{\circ} \mathrm{C} .{ }^{1} \mathrm{H}$ NMR $\left(400 \mathrm{MHz}, \mathrm{C}_{6} \mathrm{D}_{6}, 25^{\circ} \mathrm{C}\right): \delta(\mathrm{ppm})=0.52\left(\mathrm{~s}, 18 \mathrm{H}, \mathrm{SiMe}_{3}\right), 2.02(\mathrm{br}$, 1H, PCHP), 4.93 (s, 5H, $\eta^{5}-\mathrm{C}_{5} \mathrm{H}_{5}$ ), 7.06 (br, 12H, $\mathrm{Ph}_{\text {meta/para }}$ ), 7.79 (br, 8H, $\mathrm{Ph}_{\text {ortho }}$ ). ${ }^{13} \mathrm{C}\left\{{ }^{1} \mathrm{H}\right\}$ $\operatorname{NMR}\left(100 \mathrm{MHz}, \mathrm{C}_{6} \mathrm{D}_{6}, 25^{\circ} \mathrm{C}\right): \delta(\mathrm{ppm})=4.0\left(\mathrm{SiMe}_{3}\right), 37.3(\mathrm{PCHP}), 78.4\left(\eta^{5}-\mathrm{C}_{5} \mathrm{H}_{5}\right), 130.8$ $\left(\mathrm{C}_{\text {para }}\right), 131.5\left(\mathrm{C}_{\text {meta }}\right), 131.6\left(\mathrm{C}_{\text {ortho }}\right), 136.4\left(\mathrm{C}_{\text {ipso }}, \mathrm{d},{ }^{1} J_{\mathrm{CP}}=100 \mathrm{~Hz}\right), 221.4(\mathrm{CO}) .{ }^{31} \mathrm{P}\left\{{ }^{1} \mathrm{H}\right\} \mathrm{NMR}$ $\left(161 \mathrm{MHz}, \mathrm{C}_{6} \mathrm{D}_{6}, 25{ }^{\circ} \mathrm{C}\right): \delta(\mathrm{ppm})=23.6 .{ }^{29} \mathrm{Si}\left\{{ }^{1} \mathrm{H}\right\} \mathrm{NMR}\left(79 \mathrm{MHz}, \mathrm{C}_{6} \mathrm{D}_{6}, 25{ }^{\circ} \mathrm{C}\right) \delta(\mathrm{ppm})=$ -3.25. FTIR (Nujol mull, $\mathrm{cm}^{-1}$ ): 1924, 1860 ( $v(\mathrm{CO})$ ). Anal. Calc'd for $\mathrm{C}_{38} \mathrm{H}_{44} \mathrm{FeMgN}_{2} \mathrm{O}_{2} \mathrm{P}_{2} \mathrm{Si}_{2}$ : C, 60.15; H, 5.85; N, 3.69. Found: C, 59.98; H, 6.00; N, $3.75 \%$.

Crystal structure refinement and data for 1: Single crystal X-ray diffraction data was collected on a Rikagu Oxford Diffraction SuperNova operating at $90 \mathrm{~K}$ and using $\mathrm{Cu} \mathrm{K \alpha}$ radiation $(\lambda=1.54184 \AA)$. The structure was solved via direct methods and refined by fullmatrix least-squares in SHELXL-97. ${ }^{22}$ Positional disorder was identified for atoms C(33), $\mathrm{C}(35), \mathrm{C}(36)$ and $\mathrm{C}(37)$ : the occupancies of the two components were refined competitively, converging at a ratio of $0.704(14): 0.296(14)$. Extensive restraints were applied to the anisotropic displacement parameters in the affected region. CCDC-898156. $\mathrm{C}_{38} \mathrm{H}_{44} \mathrm{FeMgN}_{2} \mathrm{O}_{2} \mathrm{P}_{2} \mathrm{Si}_{2}$. Monoclinic, space group $P 2{ }_{1} / n$ (No. 14), $a=9.7075(9), b=19.283(2)$,

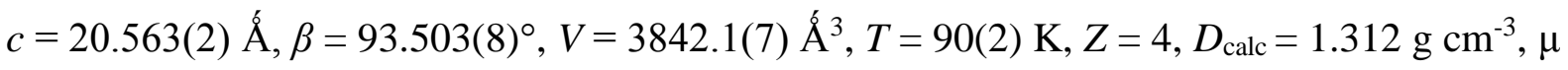
$=4.967 \mathrm{~mm}^{-1}, F(000)=1592$. Of the 16703 reflections collected, 6793 were unique, with $R_{\text {int }}$ $=0.094$. Final $R_{1}\left(w R_{2}\right)=0.0944(0.302)$ with GOF $=1.04$. Max. and min. electron densities: $0.86,-0.68$ e $\AA^{3}$. 
Details of Calculations for 1: Geometry optimisations were performed for $\mathbf{1}$ using coordinates derived from the X-ray crystal structure of this complex. No constraints were imposed on the structure during the geometry optimisations. The calculations were performed using the Amsterdam Density Functional (ADF) suite version 2014. ${ }^{23,24}$ The DFT geometry optimisations employed all-electron Slater type orbital (STO) triple- $\zeta$-plus polarisation basis sets from the ZORA/TZP database of the ADF suite. Scalar relativistic approaches were used within the ZORA Hamiltonian for the inclusion of relativistic effects and the local density approximation (LDA) with the correlation potential due to Vosko et al. ${ }^{25}$ was used in all of the calculations. Gradient corrections were performed using the functionals of $\mathrm{Becke}^{26}$ and Perdew. ${ }^{27}$ The Atoms in Molecules analysis ${ }^{28}$ was carried out with ADF2014 and Xaim-1.0 $0^{29}$ and a Natural Bond Orbital (NBO) analysis by NBO 6.0..$^{30}$

\section{Results and Discussion}

$\mathrm{CH}\left(\mathrm{Ph}_{2} \mathrm{PNSiMe}_{3}\right)_{2} \mathrm{MgFe}\left(\eta^{5}-\mathrm{C}_{5} \mathrm{H}_{5}\right)(\mathrm{CO})_{2}$ (1) has been synthesised via a salt-elimination strategy, similar to that for $\mathrm{CH}[\mathrm{C}(\mathrm{Me}) \mathrm{CNDipp}]_{2} \mathrm{Mg}(\mathrm{THF}) \mathrm{Fe}\left(\eta^{5}-\mathrm{C}_{5} \mathrm{H}_{5}\right)(\mathrm{CO})_{2}(\mathrm{Dipp}=2,6-$ $\left.{ }^{i} \mathrm{Pr}_{2} \mathrm{C}_{6} \mathrm{H}_{3}\right) .{ }^{13}$ The reaction between $\mathrm{CH}\left(\mathrm{Ph}_{2} \mathrm{PNSiMe}_{3}\right)_{2} \mathrm{MgI}(\mathrm{THF})$ and $\mathrm{Na}\left[\mathrm{Fe}\left(\eta^{5}-\mathrm{C}_{5} \mathrm{H}_{5}\right)(\mathrm{CO})_{2}\right]$ was performed in toluene, according to Scheme 1. A pure sample of $\mathbf{1}$ was obtained as a brown microcrystalline solid by the slow cooling of a concentrated toluene solution to $-35^{\circ} \mathrm{C}$ in good yield. ${ }^{1} \mathrm{H},{ }^{13} \mathrm{C}\left\{{ }^{1} \mathrm{H}\right\},{ }^{29} \mathrm{Si}\left\{{ }^{1} \mathrm{H}\right\}$ and ${ }^{31} \mathrm{P}\left\{{ }^{1} \mathrm{H}\right\}$ NMR data for $\mathbf{1}$ confirm the presence of bis(iminophosphorano)methanide, cyclopentadienyl and carbonyl ligands. The NMR signals of the BIPM ligand exhibited by $\mathbf{1}$ are broadly similar to those in $\mathrm{CH}\left(\mathrm{Ph}_{2} \mathrm{PNSiMe}_{3}\right)_{2} \mathrm{MgI}(\mathrm{THF}) .{ }^{19}$ 


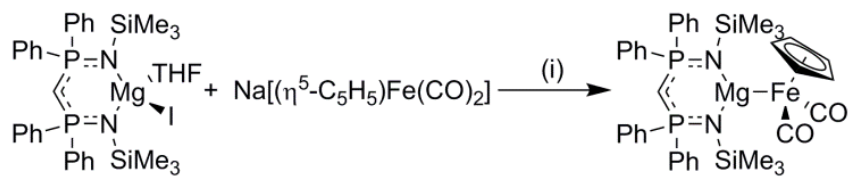

Scheme 1. Synthesis of $\mathrm{CH}\left(\mathrm{Ph}_{2} \mathrm{PNSiMe}_{3}\right)_{2} \mathrm{MgFe}\left(\eta^{5}-\mathrm{C}_{5} \mathrm{H}_{5}\right)(\mathrm{CO})_{2}$ (1). Reaction conditions: (i) Toluene, 24 hours, room temperature, $-\mathrm{NaI}$.

The carbonyl ligands in $\mathbf{1}$ provide a probe of the bonding between these two metal centres via the inspection of their stretching frequencies: at 1924, $1860 \mathrm{~cm}^{-1}$ (FTIR; nujol mull) they are consistent with the absence of bridging isocarbonyl linkages in the solid state and suggest the presence of an $\mathrm{Mg}-\mathrm{Fe}$ bond. The magnitude of the polarisation of the electron density from the $\left[\left(\eta^{5}-\mathrm{C}_{5} \mathrm{H}_{5}\right) \mathrm{Fe}(\mathrm{CO})_{2}\right]^{-}$moiety to the magnesium centre is expected to lead to higher $v(\mathrm{CO})$ values due to lower iron-carbonyl $\pi$-backbonding. ${ }^{4}$ We have used the $\Delta v(\mathrm{CO})_{\text {as }}$ parameter - the shift to a higher frequency of the asymmetric carbonyl stretch, $v(\mathrm{CO})_{\mathrm{as}}$ in relation to that for the anion in our complex with reference to the $\mathrm{K}\left[\left(\eta^{5}-\mathrm{C}_{5} \mathrm{H}_{5}\right) \mathrm{Fe}(\mathrm{CO})_{2}\right.$ salt $\left(v(\mathrm{CO})_{\mathrm{as}}=1770 \mathrm{~cm}^{-1}\right),{ }^{7 \mathrm{~b}}$ to infer the acceptor strength of $\left[\left(\eta^{5}-\mathrm{C}_{5} \mathrm{H}_{5}\right) \mathrm{Fe}(\mathrm{CO})_{2}\right]^{-31} .{ }^{31}$ For $\mathbf{1}$ $\Delta v(\mathrm{CO})_{\mathrm{as}}=90 \mathrm{~cm}^{-1}$, which is similar to that for $\mathrm{CH}[\mathrm{C}(\mathrm{Me}) \mathrm{CNDipp}]_{2} \mathrm{Mg}(\mathrm{THF}) \mathrm{Fe}\left(\eta^{5}-\right.$ $\left.\mathrm{C}_{5} \mathrm{H}_{5}\right)(\mathrm{CO})_{2}\left(\mathrm{Dipp}=2,6{ }^{-}{ }^{i} \operatorname{Pr}_{2} \mathrm{C}_{6} \mathrm{H}_{3}\right)\left[v(\mathrm{CO})_{\text {as }}=1857 \mathrm{~cm}^{-1}, \Delta v(\mathrm{CO})_{\mathrm{as}}=87 \mathrm{~cm}^{-1}\right]{ }^{13}$ and higher than that for the neodymium complex $\mathrm{L}\left\{\mathrm{N}\left(\mathrm{SiMe}_{3}\right)_{2}\right\} \mathrm{NdFe}\left(\eta^{5}-\mathrm{C}_{5} \mathrm{H}_{5}\right)(\mathrm{CO})_{2}\left(\mathrm{~L}={ }^{t} \mathrm{BuNCH}_{2} \mathrm{CH}_{2-}\right.$ $\left.\left\{\mathrm{C}\left(\mathrm{NCSiMe}_{3} \mathrm{CHN}^{t} \mathrm{Bu}\right)\right\}\right)\left[v(\mathrm{CO})_{\mathrm{as}}=1845 \mathrm{~cm}^{-1}, \Delta v(\mathrm{CO})_{\mathrm{as}}=75 \mathrm{~cm}^{-1}\right]^{6 \mathrm{c}}$ and actinide $(\mathrm{An})$ complexes $\mathrm{Cp}_{3} \mathrm{AnFe}\left(\eta^{5}-\mathrm{C}_{5} \mathrm{H}_{5}\right)(\mathrm{CO})_{2}\left[\mathrm{An}=\mathrm{Th}: v(\mathrm{CO})_{\mathrm{as}}=1855 \mathrm{~cm}^{-1}, \Delta v(\mathrm{CO})_{\mathrm{as}}=85 \mathrm{~cm}^{-1} ; \mathrm{An}\right.$ $\left.=\mathrm{U}: v(\mathrm{CO})_{\mathrm{as}}=1847 \mathrm{~cm}^{-1}, \Delta v(\mathrm{CO})_{\mathrm{as}}=77 \mathrm{~cm}^{-1}\right] .^{32}$ These data would suggest that the interaction between the iron and magnesium centres is best described by a donor/acceptor model with a large ionic contribution, and slightly more electron withdrawing than the neodymium and actinide fragments in these complexes, ${ }^{6 c, 32}$ although this difference is small. The $\Delta v(\mathrm{CO})_{\text {as }}$ value of $90 \mathrm{~cm}^{-1}$ for $\mathbf{1}$ is lower than that in the early transition metal complexes $\left(3,5-{ }^{i} \operatorname{Pr}_{2}-2,6-\right.$ 
$\left.\operatorname{Trip}_{2} \mathrm{C}_{6} \mathrm{H}\right) \mathrm{Cr}-\mathrm{Fe}\left(\eta^{5}-\mathrm{C}_{5} \mathrm{H}_{5}\right)(\mathrm{CO})_{2}\left[v(\mathrm{CO})_{\mathrm{as}}=1879 \mathrm{~cm}^{-1}, \Delta v(\mathrm{CO})_{\mathrm{as}}=109 \mathrm{~cm}^{-1}\right.$; Trip = 2,4,6$\left.{ }^{i} \operatorname{Pr}_{3} \mathrm{C}_{6} \mathrm{H}_{2}\right],{ }^{2}$ and $\mathrm{Me}\left(\mathrm{CH}_{2} \mathrm{SiMe}_{3} \mathrm{~N}\right)_{3} \mathrm{Ti}-\mathrm{Fe}\left(\eta^{5}-\mathrm{C}_{5} \mathrm{H}_{5}\right)(\mathrm{CO})_{2}\left[v(\mathrm{CO})_{\mathrm{as}}=1916 \mathrm{~cm}^{-1}, \Delta v(\mathrm{CO})_{\mathrm{as}}=146\right.$ $\left.\mathrm{cm}^{-1}\right] .{ }^{33}$ As a reference point, typically covalent systems such as alkyl-Fe $\left(\eta^{5}-\mathrm{C}_{5} \mathrm{H}_{5}\right)(\mathrm{CO})_{2}$ have $\Delta v(\mathrm{CO})_{\text {as }} c a .170-185 \mathrm{~cm}^{-1},{ }^{31,34}$ while the values for analogous boryl complexes which feature appreciable $\mathrm{Fe}-\mathrm{B}$ multiple bond character have yet higher $\Delta v(\mathrm{CO})_{\text {as }}$ values. ${ }^{\text {a-c }}$

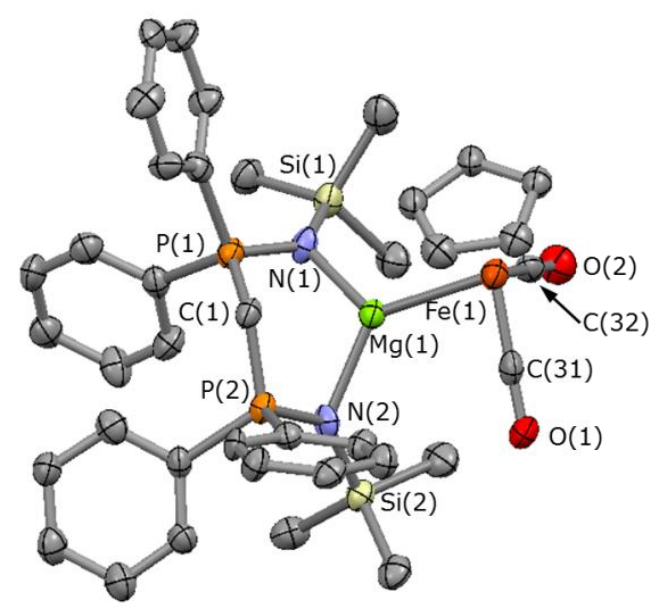

Figure 1. Crystal structure of 1, with displacement ellipsoids set at 50\% probability. Hydrogen atoms are omitted for clarity.

Single crystals of 1 suitable for X-ray diffraction were grown from a concentrated toluene solution at $7{ }^{\circ} \mathrm{C}$. The X-ray crystal structure of 1 (Fig.1; relevant bond lengths and angles can be found in Table 1) shows that it features an unsupported $\mathrm{Mg}-\mathrm{Fe}$ bond, and is monomeric in the solid state. The structure of $\mathbf{1}$ displays the expected half sandwich geometry at the iron centre. The magnesium centre sits in a plane created by the two ligand nitrogen atoms and the iron atom in a trigonal planar environment $\left(\Sigma\right.$ angles around $\left.\mathrm{Mg}=359.6^{\circ}\right)$. Additionally there is a close approach of the central methanide of the $\left[\mathrm{CH}\left(\mathrm{Ph}_{2} \mathrm{PNSiMe}_{3}\right)_{2}\right]^{-}$ ligand to the magnesium centre $[\mathrm{Mg}(1) \cdots \mathrm{C}(1)=2.471(8) \AA]$, which causes the $\mathrm{MgN}_{2} \mathrm{P}_{2} \mathrm{C}$ ring to adopt a pseudo-boat conformation. The adoption of this conformation can be ascribed to the 
Lewis acidity of the $\mathrm{Mg}^{2+}$ ion ${ }^{19}$ and has been observed previously. ${ }^{35} \mathrm{The} \mathrm{Mg} \cdots \mathrm{C}(1)$ distance in $\mathbf{1}$ is shorter than that for the halide complex $\mathrm{CH}\left(\mathrm{Ph}_{2} \mathrm{PNSiMe}_{3}\right)_{2} \mathrm{MgI}(\mathrm{THF})$ [2.573(6) $\AA$ ] and is similar to that for $\left[\mathrm{HC}\left(\mathrm{Ph}_{2} \mathrm{PNSiMe}_{3}\right)_{2} \mathrm{Mg}(\mu-\mathrm{Cl})\right]_{2}[2.460(8) \AA]$. This short $\mathrm{Mg} \cdots \mathrm{C}$ distance suggests a highly electropositive $\mathrm{Mg}$ centre and lends further credence to the presence of a primarily ionic interaction between the magnesium and iron centres. The $\mathrm{Mg}-\mathrm{Fe}$ distance of 2.530 (3) $\AA$ lies within the sum of the covalent radii for these two elements $(2.55 \AA) .{ }^{36}$ This distance is significantly shorter than that for $(\mathrm{Piso}-\mathrm{H}) \mathrm{Fe}(\mu-\mathrm{H}) \mathrm{Mg}(\mathrm{THF})\left(\mathrm{CH}[\mathrm{C}(\mathrm{Me}) \mathrm{CNMes}]_{2}\right)$ $\left[2.741 \AA ; \mathrm{Piso}^{-}=(\mathrm{DippN})_{2} \mathrm{C}^{t} \mathrm{Bu}, \mathrm{Mes}=2,4,6-\mathrm{Me}_{3} \mathrm{C}_{6} \mathrm{H}_{2}\right]^{37}$ and $(\mathrm{THF})_{2} \mathrm{MgCl}(\mu-\mathrm{N}-\mathrm{PNP}) \mathrm{Fe}(\mu-$ H)N 2 [2.6026(15) $\AA$; $\mathrm{PNP}^{-}=\operatorname{bis}\left(2\right.$-(diisopropylphosphanyl)-4-methylphenyl)amido], ${ }^{38}$ which feature magnesium-iron interactions supported by bridging hydrides, and the direct, unsupported $\quad(\mathrm{THF})_{2}(\mathrm{Br}) \mathrm{Mg}-\mathrm{Fe}\left(\eta^{5}-\mathrm{C}_{5} \mathrm{H}_{5}\right)(\mathrm{dppe}) \quad[2.593(7) \quad \AA] \quad(\mathrm{dppe} \quad=\quad 1,2-$ bis(diphenylphosphino)ethane $)^{8} \quad$ and $\quad \mathrm{CH}[\mathrm{C}(\mathrm{Me}) \mathrm{CNDipp}]_{2} \mathrm{Mg}(\mathrm{THF}) \mathrm{Fe}\left(\eta^{5}-\mathrm{C}_{5} \mathrm{H}_{5}\right)(\mathrm{CO})_{2}$ $[2.6326(4) \AA]^{13}$ presumably due to the lower coordination number in $\mathbf{1}$.

Table 1. Selected bond lengths $(\AA)$ and angles $\left(^{\circ}\right)$ for $\mathbf{1}$ derived from the experimental X-ray crystal structure and by DFT calculations.

\begin{tabular}{lll}
\hline Bond Length $(\AA) /$ Angle $\left(^{\circ}\right)$ & Experimental & Calculated \\
\hline $\mathrm{Fe}(1)-\mathrm{Mg}(1)$ & $2.530(3)$ & 2.525 \\
$\mathrm{Fe}(1)-\mathrm{C}(31)$ & $1.721(9)$ & 1.728 \\
$\mathrm{Fe}(1)-\mathrm{C}(32)$ & $1.710(9)$ & 1.732 \\
$\mathrm{P}(1)-\mathrm{N}(1)$ & $1.593(7)$ & 1.617 \\
$\mathrm{P}(2)-\mathrm{N}(2)$ & $1.598(6)$ & 1.617 \\
$\mathrm{Si}(1)-\mathrm{N}(1)$ & $1.733(7)$ & 1.763
\end{tabular}




\begin{tabular}{|c|c|c|}
\hline $\mathrm{Si}(2)-\mathrm{N}(2)$ & $1.717(7)$ & 1.758 \\
\hline $\operatorname{Mg}(1)-\mathrm{N}(1)$ & $2.076(7)$ & 2.116 \\
\hline $\mathrm{Mg}(1)-\mathrm{N}(2)$ & $2.112(8)$ & 2.135 \\
\hline $\operatorname{Mg}(1) \cdots C(1)$ & $2.471(8)$ & 2.545 \\
\hline $\operatorname{Mg}(1) \cdots C(31)$ & $2.898(9)$ & 2.996 \\
\hline $\operatorname{Mg}(1) \cdots C(32)$ & $3.018(9)$ & 2.876 \\
\hline $\mathrm{C}(32)-\mathrm{Fe}(1)-\mathrm{C}(31)$ & $92.0(4)$ & 93.5 \\
\hline $\mathrm{C}(32)-\mathrm{Fe}(1)-\mathrm{Mg}(1)$ & $88.6(3)$ & 82.8 \\
\hline $\mathrm{C}(31)-\mathrm{Fe}(1)-\mathrm{Mg}(1)$ & $83.7(3)$ & 87.5 \\
\hline $\mathrm{N}(1)-\mathrm{Mg}(1)-\mathrm{N}(2)$ & 107.4(3) & 107.6 \\
\hline $\mathrm{N}(1)-\mathrm{Mg}(1)-\mathrm{Fe}(1)$ & $123.7(2)$ & 124.1 \\
\hline $\mathrm{N}(2)-\mathrm{Mg}(1)-\mathrm{Fe}(1)$ & $128.5(2)$ & 127.1 \\
\hline $\mathrm{Fe}(1)-\mathrm{C}(31)-\mathrm{O}(1)$ & $178.9(8)$ & 176.9 \\
\hline $\mathrm{Fe}(1)-\mathrm{C}(32)-\mathrm{O}(2)$ & $176.7(8)$ & 177.3 \\
\hline
\end{tabular}

Inspection of the crystal structure of $\mathbf{1}$ also affords a detailed analysis of the nature of any interactions between the highly electropositive magnesium centre and the iron-bound $\mathrm{CO}$ ligands in the solid state. The $\mathrm{Fe}-\mathrm{C}-\mathrm{O}$ moieties are linear $\left[178.9(8)^{\circ}\right.$ and $\left.176.7(8)^{\circ}\right]$ and the Fe-C distances $[1.721(9), 1.710(9) \AA]$ are typical for terminal Fe-CO bonds. ${ }^{39}$ Furthermore, the bridge asymmetry parameter, $\alpha$, for the $\operatorname{Mg}(1) \cdots \mathrm{C}$ interactions, has been calculated as 0.68 
for $\mathrm{C}(31)$ and 0.76 for $\mathrm{C}(32)$, indicating that the ligands are essentially terminal (a value of $\geq$ $0.6) .^{40}$

In order to probe further the bonding in $\mathbf{1}$, DFT calculations were performed on the optimised structure of this complex using coordinates derived from the X-ray crystal structure. The principal features of the coordination spheres about the $\operatorname{Mg}(1)$ and $\mathrm{Fe}(1)$ centres, as revealed by X-ray crystallographic studies of $\mathbf{1}$, are reproduced in the DFT calculations. These include the relatively short $\mathrm{Fe}(1)-\mathrm{Mg}(1)$ interaction and the metal-ligand distances about each metal centre that are reproduced to within $c a$. 0.03-0.04 $\AA$ of the experimental values. Thus, given the similarities between the calculated and experimental structures we conclude that the DFT calculations of $\mathbf{1}$ can provide a qualitative description of the electronic structure of $\mathbf{1}$.

The DFT calculations reveal a Nalewajski-Mrozek bond index ${ }^{41}$ of 0.2093 for the Fe$\mathrm{Mg}$ interaction in $\mathbf{1}$ and we examined the nature of this interaction using the energy decomposition analysis (EDA) method that is incorporated within the ADF code. ${ }^{23,24}$ In using this approach, the interaction energy $\Delta \mathrm{E}_{\mathrm{i}}$ between two fragments is decomposed into $\Delta \mathrm{E}_{\mathrm{i}}=$ $\Delta \mathrm{E}_{\text {steric }}+\Delta \mathrm{E}_{\mathrm{oi}}$, where $\Delta \mathrm{E}_{\text {steric }}$ is the steric interaction energy between the two fragments in geometries that are identical to those in the parent molecule and $\Delta \mathrm{E}_{\mathrm{oi}}$ is the orbital contribution to the interaction energy. $\Delta \mathrm{E}_{\text {steric }}$ comprises the destabilising repulsive interactions between occupied MOs $\left(\Delta \mathrm{E}_{\text {Pauli }}\right)$ and the classical electrostatic interaction $\left(\Delta \mathrm{E}_{\text {elstat }}\right)$ between the fragments; $\Delta \mathrm{E}_{\mathrm{oi}}$ accounts for electron pair bonding, charge transfer, and orbital polarisation. In order to perform the EDA analysis we constructed $\left[\left(\eta^{5}-\mathrm{C}_{5} \mathrm{H}_{5}\right) \mathrm{Fe}(\mathrm{CO})_{2}\right]^{-}$and $\left[\mathrm{MgCH}\left(\mathrm{Ph}_{2} \mathrm{PNSiMe}_{3}\right)_{2}\right]^{+}$fragments in identical geometries to those in $\mathbf{1}$. The results of the EDA analysis for the $\mathrm{Mg}-\mathrm{Fe}$ interaction in $\mathbf{1}$ are shown in Table 2 and reveal a dominant electrostatic contribution; $69 \%$ of the total attractive interaction derives from $\Delta \mathrm{E}_{\text {elstat }}$ interactions. 
We carried out a topological analysis of the electron density of 1 using Bader's Atoms in Molecules (QTAIM) ${ }^{29}$ to provide further insight into the Fe-Mg interaction in 1. In QTAIM, a chemical bond is defined by the presence of a line of locally maximum electron density $[\rho(\mathbf{r})]$ along a bond path between two atoms and a bond critical point (BCP) which is the minimum in the electron density along this line. The Laplacian of the electron density $\left[\nabla^{2} \rho(\mathbf{r})\right]$ is the scalar derivative of the gradient vector field of the electron density; $\nabla^{2} \rho(\mathbf{r})<0$ describes an area where the electronic charge is locally concentrated whereas $\nabla^{2} \rho(\mathbf{r})>0$ defines a region of electronic charge depletion. The electronic energy density $H(\mathbf{r})$ of the charge distribution is defined as $H(\mathbf{r})=G(\mathbf{r})+V(\mathbf{r})$ where $G(\mathbf{r})$ is the kinetic energy density and $V(\mathbf{r})$ is the potential energy. For a covalent shared-shell interactions $\nabla^{2} \rho(\mathbf{r})<0$ and $H(\mathbf{r})<0$ and for purely closedshell interactions $\nabla^{2} \rho(\mathbf{r})>0$ and $H(\mathbf{r})>0$. For interactions where $\nabla^{2} \rho(\mathbf{r})>0$ and $H(\mathbf{r})<0$, the negative value of $H(\mathbf{r})$ may be considered as reflecting a degree of covalency in the interaction. ${ }^{42}$ QTAIM identifies a BCP between the Fe and Mg centres in 1 (Figure 2) with values of $[\rho(\mathbf{r})],\left[\nabla^{2} \rho(\mathbf{r})\right]$, and $H(\mathbf{r})$ at this point of $0.0325,0.0682$ and -0.0052 , respectively, and support a predominantly ionic interaction with between these centres as revealed by the results of the EDA (see above). The calculated Wiberg bond index between the Fe and $\mathrm{Mg}$ centres $(0.4212)$ and the natural charges $(-0.4486$ and 1.6940 , respectively) derived from a Natural Bond Orbital (NBO) analysis ${ }^{30}$ of $\mathbf{1}$ lend further support to this description. NBO also identifies the key donor-acceptor (bond-antibond) interaction that represents the covalent contribution to the bonding between $\mathrm{Fe}$ and $\mathrm{Mg}$ in $\mathbf{1}$. This interaction involves a non-bonded (lone-pair) $\mathrm{Fe} 3 d$ orbital and an unfilled non-bonded $3 \mathrm{~s} \mathrm{Mg}$ orbital, and second-order perturbation theory provides an estimate of this donor-acceptor interaction in the NBO basis of $58.2 \mathrm{kcal} \mathrm{mol}^{-1}$. 
Table 2. Energy Decomposition Analysis (EDA) for the Fe-Mg interaction in $\mathbf{1}$.

\begin{tabular}{ll}
\hline Term & Energy $/ \mathrm{kcal} \mathrm{mol}^{-1}$ \\
\hline$\Delta \mathrm{E}_{\text {Pauli }}$ & 56.7 \\
$\Delta \mathrm{E}_{\text {elstat }}$ & -129.5 \\
$\Delta \mathrm{E}_{\text {steric }}=\Delta \mathrm{E}_{\text {Pauli }}+\Delta \mathrm{E}_{\text {elstat }}$ & -72.8 \\
$\Delta \mathrm{E}_{\mathrm{oi}}$ & -57.2 \\
$\Delta \mathrm{E}_{\mathrm{i}}$ & -130.2 \\
\hline
\end{tabular}

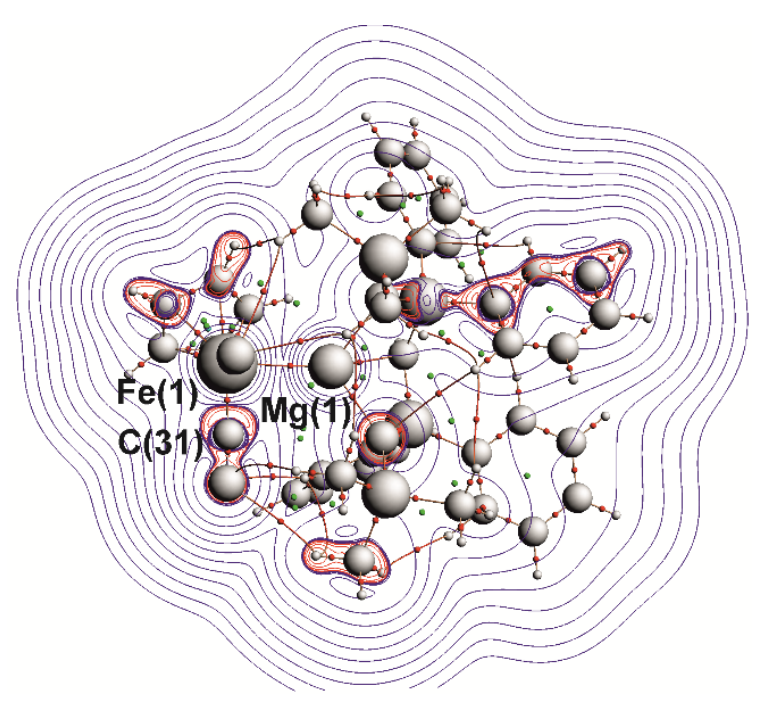

Figure 2. A molecular graph derived from a QTAIM analysis of 1. Bond critical points (BCP) and ring critical points (RCP) are shown as red and green spheres, respectively, the atom critical points are shown as grey spheres scaled by electron density and the solid lines connecting the nuclei are the bond paths. The contour plot of the Lapacian of the electron density $\nabla^{2} \rho(\mathbf{r})$ is plotted for the plane containing the $\mathrm{C}(31), \mathrm{Fe}(1)$ and $\mathrm{Mg}(1)$. The contour lines (in hartrees) are $10^{-5}$ for the outermost line and then $10^{\mathrm{n}}(\mathrm{n}=-4.5,-4.0,-3.5 \ldots$.$) . The contour lines in blue and$ red represent areas where $\nabla^{2} \rho(\mathbf{r})>0$ and $<0$, respectively. 


\section{Conclusions}

We have synthesised and characterised $\mathrm{CH}\left(\mathrm{Ph}_{2} \mathrm{PNSiMe}_{3}\right)_{2} \mathrm{Mg}-\mathrm{Fe}\left(\eta^{5}-\mathrm{C}_{5} \mathrm{H}_{5}\right)(\mathrm{CO})_{2}$ (1), which features an unsupported Ae-TM bond. The FTIR-measured carbonyl stretching frequencies for $\mathbf{1}$ suggest that there is a polarisation of charge from the $\left[\left(\eta^{5}-\mathrm{C}_{5} \mathrm{H}_{5}\right) \mathrm{Fe}(\mathrm{CO})_{2}\right]$ fragment to the magnesium centre. The presence of the polar metal-metal bond in $\mathbf{1}$ is confirmed by DFT calculations, which suggest that the $\mathrm{Mg}-\mathrm{Fe}$ bond is predominantly ionic in nature.

\section{Acknowledgements}

We thank the EPSRC and the University of Nottingham for financial support of this research. We also thank Mr Stephen Boyer (Microanalysis Service, London Metropolitan University) for elemental analysis.

\section{References}

[1] Multiple Bonds Between Metal Atoms, 3rd Edn., (Eds. F.A. Cotton, C.A. Murillo, R.A. Walton) Springer, New York, N.Y., 2005.

[2] H. Lei, J.-D. Guo, J.C. Fettinger, S. Nagase, P.P. Power, J. Am. Chem. Soc. 132 (2010) 17399-17401.

[3] L.H. Gade, Angew. Chem. Int. Ed. 39 (2000) 2658-2678.

[4] B.M. Gardner, D. Patel, A.D. Cornish, J. McMaster, W. Lewis, A.J. Blake, S.T. Liddle, Chem. Eur. J. 17 (2011) 11266-11273.

[5] a) D.L. Kays (née Coombs), S. Aldridge, Struct. Bond. 130 (2008) 29-122; b) S. Aldridge, D.L. Kays (née Coombs), Main Group Chem. 5 (2006) 223-249; c) S. Aldridge, D.L. 
Coombs, Coord. Chem. Rev. 248 (2004) 535-559; d) C. Gemel, T. Steinke, M. Cokoja, A. Kempter, R.A. Fischer, Eur. J. Inorg. Chem. (2004) 4161-4176; e) A.H. Cowley, J. Organomet. Chem. 689 (2004) 3866-3872; f) G. Linti, H.-G. Schnöckel, Coord. Chem. Rev. 206-207 (2000) 285-319; g) H. Ogino, H. Tobita, Adv. Organomet. Chem. 42 (1998) 223-290; h) M.F. Lappert, R.S. Rowe, Coord. Chem. Rev. 100 (1990) 267-292, and references cited therein.

[6] a) I.P. Beletskaya, A.Z. Voskoboynikov, E.B. Chuklanova, N.I. Kirillova, A.K. Shestakova, I.N. Parshina, A.I. Gusev, G.K.-I. Magomedov, J. Am. Chem. Soc. 115 (1993) 3156-3166; b) M.V. Butovskii, O.L. Tok, F.R. Wagner, R. Kempe, Angew. Chem. Int. Ed. 47 (2008) 6469-6472; c) P.L. Arnold, J. McMaster, S.T. Liddle, Chem. Commun. (2009) 818820; d) C. Döring, A.-M. Dietel, M.V. Butovskii, V. Bezugly, F.R. Wagner, R. Kempe, Chem. Eur. J. 16 (2010) 10679-10683; e) M.V. Butovskii, C. Döring, V. Bezugly, F.R. Wagner, Y. Grin, R. Kempe, Nat. Chem. 2 (2010) 741-744.

[7] a) R.S. Sternal, C.P. Brock, T.J. Marks, J. Am. Chem. Soc. 107 (1985) 8270-8272; b) B.M. Gardner, J. McMaster, W. Lewis, S.T. Liddle, Chem. Commun. (2009) 2857-2859; c) D. Patel, D.M. King, B.M. Gardner, J. McMaster, W. Lewis, A.J. Blake, S.T. Liddle, Chem. Commun. 47 (2011) 295-297; d) B.M. Gardner, J. McMaster, F. Moro, W. Lewis, A.J. Blake, S.T. Liddle, Chem. Eur. J. 17 (2011) 6909-6912; e) D. Patel, F. Moro, J. McMaster, W. Lewis, A.J. Blake, S.T. Liddle, Angew. Chem. Int. Ed. 50 (2011) 10388-10392.

[8] H. Felkin, P.J. Knowles, B. Meunier, A. Mitschler, L. Ricard, R. Weiss, J. Chem. Soc., Chem. Commun. (1974) 44.

[9] K. Jonas, G. Koepe, C. Krüger, Angew. Chem. Int. Ed. Engl. 10 (1986) 923-925.

[10] W. Kaschube, K.-R. Pörschke, K. Angermund, C. Krüger, G. Wilke, Chem. Ber. 121 (1988) 1921-1929. 
[11] H. Braunschweig, K. Gruss, K. Radacki, Angew. Chem. Int. Ed. 48 (2009) 4239-4241.

[12] M.P. Blake, N. Kaltsoyannis, P. Mountford, J. Am. Chem. Soc. 133 (2011) 1535815361.

[13] M.P. Blake, N. Kaltsoyannis, P. Mountford, Chem. Commun. 49 (2013) 3315-3317.

[14] J. Hicks, C.E. Hoyer, B. Moubaraki, G. Li Manni, E. Carter, D.M. Murphy, K.S. Murray, L. Gagliardi, C. Jones, J. Am. Chem. Soc. 136 (2014) 5283-5286.

[15] O. Ekkert, A.J.P. White, H. Toms, M.R. Crimmin, Chem. Sci. 6 (2015) 5617-5622.

[16] M.P. Blake, N. Kaltsoyannis, P. Mountford, J. Am. Chem. Soc., 137 (2015) 1235212368.

[17] R. Green, A.C. Walker, M.P. Blake, P. Mountford, Polyhedron 116 (2016) 64-75.

[18] a) S.T. Liddle, D.P. Mills, A.J. Wooles, Chem. Soc. Rev. 40 (2011) 2164-2176; b) T.K. Panda, P.W. Roesky, Chem. Soc. Rev. 38 (2009) 2782-2804; c) T. Cantat, N. Mézailles, A. Auffrant, P. Le Floch, Dalton Trans. (2008) 1957-1972; d) N.D. Jones, R.G. Cavell, J. Organomet. Chem. 690 (2005) 5485-5496; e) R.G. Cavell, R.P. Kamalesh Babu, K. Aparna, J. Organomet. Chem. 617-618 (2001) 158-169.

[19] P. Wei, D.W. Stephan, Organometallics 22 (2003) 601-604.

[20] a) S.T. Liddle, D.P. Mills, B.M. Gardner, J. McMaster, C. Jones, W. Woodul, Inorg. Chem. 48 (2009) 3520-3522; b) S. Schulz, S. Gondick, D. Schuchmann, U. Westphal, A. Dobrzycki, R. Boese, S. Harder, Chem. Commun. 46 (2010) 7757-7759.

[21] R.B. King, K.H. Pannell, Inorg. Chem. 7 (1968) 1510-1513.

[22] G. M. Sheldrick, Acta Crystallogr. Sect. A: Found. Crystallogr. 64 (2008) 112-122. 
[23] C. Fonseca Guerra, J. G. Snijders, G. te Velde, E. J. Baerends, Theor. Chem. Acc. 99 (1998) 391-403.

[24] G. te Velde, F.M. Bickelhaupt, S.J.A. van Gisbergen, C. Fonseca Guerra, E.J. Baerends, J.G. Snijders, T. Ziegler, J. Comput. Chem. 22 (2001) 931-967.

[25] S.H. Vosko, L. Wilk, M. Nusair, Can. J. Phys. 58 (1980) 1200-1211.

[26] A.D. Becke, Phys. Rev. A. 38 (1988) 3098-3100.

[27] J.P. Perdew, Phys. Rev. B., 33 (1986) 8822-8824.

[28] (a) R.F.W. Bader, Atoms in Molecules: A Quantum Theory, Oxford University Press, New York, 1990; (b) R.F.W. Bader, J. Phys. Chem. A. 102 (1998) 7314-7323.

[29] http://www.quimica.urv.es/XAIM.

[30] NBO 6.0. E. D. Glendening, J. K. Badenhoop, A. E. Reed, J. E. Carpenter, J. A. Bohmann, C. M. Morales, C. R. Landis, and F. Weinhold, Theoretical Chemistry Institute, University of Wisconsin, Madison (2013).

[31] R.A. Fischer, T. Priermeier, Organometallics 13 (1994) 4306-4314.

[32] R.S. Sternal and T.J. Marks, Organometallics 6 (1987) 2621-2623.

[33] S. Friedrich, H. Memmler, L.H. Gade, W. S. Li, I. J. Scowen, M. McPartlin and C. E. Housecroft, Inorg. Chem., 35 (1996) 2433-2441. Care must be taken with comparison of the FTIR spectra between 1 and $\mathrm{Me}\left(\mathrm{CH}_{2} \mathrm{SiMe}_{3} \mathrm{~N}\right)_{3} \mathrm{Ti}-\mathrm{Fe}\left(\eta^{5}-\mathrm{C}_{5} \mathrm{H}_{5}\right)(\mathrm{CO})_{2}$ as the IR spectrum of the latter was recorded as the toluene solution, not as a Nujol mull.

[34] a) E. A. Hill and B. Li Organometallics 17 (1998) 2778-2783; b) A.H. Robertson, G.P. McQuillian, D.C. McKean, J. Chem. Soc., Dalton Trans. (1995) 3955-3961; c) Pannell, K. H.; 
Kapoor, R. N.; Wells, M.; Giasolli, T.; Parkanyi, L. Organometallics 6 (1987) 663-667; d) M. L. H. Green and M. J. Smith, J. Chem. Soc. A (1971) 3220-3221.

[35] P.W. Roesky, Z. Anorg. Allg. Chem. 632 (2006) 1918-1926.

[36] P. Pyykkö, M. Atsumi, Chem. Eur. J. 15 (2009) 186-197.

[37] L. Fohlmeister, S. Liu, C. Schulten, B. Moubaraki, A. Stasch, J.D. Cashion, K.S. Murray, L. Gagliardi, C. Jones, Angew. Chem. Int. Ed. 51 (2012) 8294-8298.

[38] L.J. Hounjet, D. Adhikari, M. Pink, P.J. Carroll, D.J. Mindiola, Z. Anorg. Allg. Chem. $641(2015)$ 45-48.

[39] R. D. Theys, M. E. Dudley, M. M. Hossain, Coord. Chem. Rev. 253 (2009) 180-234, and references cited therein.

[40] a) R. J. Klingler, W. M. Butler and M. D. Curtis, J. Am. Chem. Soc. 100 (1978) 50345039; b) M. D. Curtis, K. R. Han and W. M. Butler, Inorg. Chem. 19 (1980) 2096-2101; c) S. R. Parmelee, N. P. Mankad, Dalton Trans. 44 (2015) 17007-17014

[41] A. Michalak, R.L. De Kock and T. Ziegler, J. Phys. Chem. A 112 (2008) 7256-7263.

[42] D. Cremer and E. Kraka, Angew. Chem., Int. Ed. Engl., 23 (1984) 627-628. 